
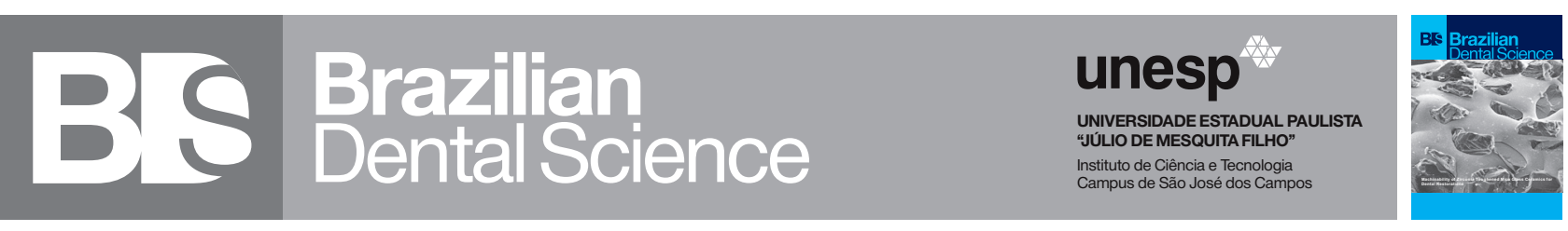

\title{
Evaluation of oral pathologic lesions in elderly patients in Isfahan, Iran, 1989-2018 years
}

Avaliação de lesões patológicas orais em pacientes idosos em Isfahan, Irã, entre 1989 e 2018

Laleh MALEKI ${ }^{1}$, Neda KARGAHI ${ }^{1}$, Seyed Ehsan HATEFI ${ }^{2}$

1 - Department of Oral and Maxillofacial Pathology, Dental Research Center, Dental Research Institute, School of Dentistry, Isfahan University of Medical Sciences, Isfahan, Iran.

2 - Dental Students Research Committee, School of Dentistry, Isfahan University of Medical Sciences, Isfahan, Iran.

\section{ABSTRACT}

Objective: One of the most important alterations in elderly is the destruction and loss of teeth and oral mucosal lesions. The aim of this study was to determine the frequency of biopsed pathologic lesions in elderly registered in the pathology department of Isfahan University of Medical Sciences during 1989 to 2018 years. Material and Methods: This crosssectional descriptive-analytic study was performed on pathologic lesions in elderly archived in Faculty of Dentistry, Isfahan University of Medical Sciences. In this study, all archived information of elderly over 65 years including gender, age, location of lesion, clinical diagnosis, pathology diagnosis, and diagnosis year were evaluated in last three decades, and were analyzed statistically. Results: The age range of elderly patients was 65 to 90 years with a mean of $72.8 \pm 4.9$. The highest frequency for location of lesions was related to mandibular vestibule (21.1\%). The most clinical diagnosed lesions were squamous cell carcinoma (24.5\%) and Epulis Fissuratum (13.4\%). The highest pathologic diagnosed lesions were related to reactive lesions group (35.6\%). The squamous cell carcinoma malignancies and other malignancies were increased significantly in elderly patients with high age. Conclusion: According to the considerable frequency of oral lesions in elderly and increased frequency of squamous cell carcinoma and other malignancies, attention to oral lesions in elderly and periodic examinations are important to early diagnosis and treatment.

\section{KEYWORDS}

Pathology; Biopsy; Elderly; Oral lesions; Isfahan.

\section{RESUMO}

Objetivo: Uma das alterações mais importantes no idoso é a destruição e perda de dentes; e lesões da mucosa oral. O objetivo deste estudo foi determinar a frequência de lesões patológicas biopsiadas em idosos registrados no departamento de patologia da Universidade de Ciências Médicas de Isfahan durante os anos de 1989 a 2018. Material e métodos: Este estudo transversal descritivo-analítico foi realizado em lesões patológicas em idosos arquivadas na Faculdade de Odontologia da Universidade de Ciências Médicas de Isfahan. Neste estudo, todas as informações arquivadas de idosos com mais de 65 anos, incluindo sexo, idade, localização da lesão, diagnóstico clínico, diagnóstico patológico e ano do diagnóstico foram avaliadas nas últimas três décadas e foram analisadas estatisticamente. Resultados: A faixa etária dos pacientes idosos foi de 65 a 90 anos, com média de $72,8 \pm 4,9$. A maior frequência de localização das lesões foi relacionada a região vestibular da mandíbula $(21,1 \%)$. As lesões mais diagnosticadas clinicamente foram carcinoma espinocelular (24,5\%) e Epulis Fissuratum (13,4\%). As maiores lesões patológicas diagnosticadas foram relacionadas ao grupo de lesões reativas (35,6\%). As neoplasias do carcinoma de células escamosas e outras neoplasias aumentaram significativamente em pacientes idosos com alta idade. Conclusão: Devido à considerável frequência de lesões orais em idosos e ao aumento da frequência de carcinoma espinocelular e outras neoplasias, a atenção às lesões orais em idosos e os exames periódicos são importantes para o diagnóstico e tratamento precoces.

\section{PALAVRAS-CHAVE}

Patologia; Biópsia; Idoso; Lesões orais; Isfahan. 


\section{INTRODUCTION}

E lderly are exposed to various diseases due to physiological and pathological alterations. One of the most important alterations in elderly is tooth decay and loss.Oral health plays an important role in determining dietary pattern and consequently health and life quality of elderly. Therefore, elderly need dental care more than other age groups $[1,2]$.

In addition to dental caries, various oral and dental problems are common among elderly, include dryness and thinning of oral mucosa, loss of taste, smooth and glossy tongue, gum resorption and reduction in oral tissue repair, as well as various gum diseases, infection, inappropriate artificial teeth, and malignant and benign oral lesions $[3,4]$. Use of removable prosthesis can cause some oral mucosal lesions such as osteomyelitis, angular cheilitis, inflammation, and traumatic ulcer. Moreover, vascular lesions such as varicose veins and pre-cancerous lesions such as leukoplakia and erythroplakia are more common in the elderly than in other ages $[5,6]$.

Due to rising average age of people around the world, an important part of the population is older people.In order to management of various diseases, it is necessary to determine its prevalence in target people. The prevalence of oral pathologic lesions can be different in people with geographical, cultural, ethnic, and racial different $[7,8]$. Therefore, the aim of this study was to evaluate frequency of biopsed pathologic lesions in elderly people over 65 years old in Isfahan City, Iran, during 1989 to 2018 years.

\section{MATERIAL AND METHODS}

The present descriptive-analytic study was performed on pathologic lesions in elderly (over 65 years old) recorded in the Pathology Department, Faculty of Dentistry, Isfahan University of Medical Sciences, 1989-2018 years. The inclusion criteria included patients older than 65 years, in the last 30 years. Also, the exclusion criteria included incomplete and confounded data with invalid information. The information of all biopsed patients including sex, age, biopsy area, clinical diagnosis, pathologic diagnosis, and diagnosis year were collected. The obtained data were analyzed by chi-square test using SPSS (version 22) software. The $\mathrm{p}<$ 0.05 were considered as statically significant. The present study was performed according to the Declaration of Helsinki ethical standards. The ethical code was IR.MUI.RESEARCH. REC.1398.129.

\section{RESULTS}

In the present study, the records and pathological reports of 744 elderly patients (65-90 years, $72.8 \pm 4.9$ ) were evaluated.374 patients $(50.3 \%)$ were male and 370 patients $(49.7 \%)$ were female. There was no significant difference between men and women in prevalence of pathological lesions ( $\mathrm{p}>$ 0.05).327 patients (44\%) were in $65-70$ years old, 321 patients $(43.1 \%)$ were in $71-79$ years old, and 96 patients (12.9\%) were in 80-90 years old.

The most frequent lesions were in the mandibular vestibule (21.1\%) and the least in the oropharynx $(0.3 \%)$.Except for cases without clinical diagnosis (29.4\%), the most frequent pre-biopsy lesions were squamous cell carcinoma (24.5\%), followed by Epulis fissuratum (13.4\%). Most pathologic lesions were squamous cell carcinoma $(21.7 \%)$ followed by Epulis fissuratum (18.4\%), irritation fibroma (5.8\%), peripheral giant-cell granuloma (5.4\%), lichen planus (4.8\%), and odontogenic keratocyst (3.6\%).The most common lesions were reactive lesions $(35.6 \%)$ and squamous cell carcinoma (21.7\%).Frequency of all lesions are presented in Table I. 
Table I - Frequency of pathological lesions in elderly patients.

\begin{tabular}{|c|c|c|}
\hline Lesions & Number (No.) & Percentage(\%) \\
\hline Reactive lesions & 265 & 35.6 \\
\hline Squamous Cell Carcinoma & 161 & 21.7 \\
\hline $\begin{array}{l}\text { Other malignancies than squa- } \\
\text { mous cell carcinoma }\end{array}$ & 62 & 8.3 \\
\hline Odontogenic lesions & 41 & 5.5 \\
\hline Immunological and allergic lesions & 57 & 7.7 \\
\hline Other lesions & 158 & 21.2 \\
\hline Total & 744 & 100 \\
\hline
\end{tabular}

Frequency of lesions has been rising in the last three decades, and the highest frequency was observed in the recent decade (2009-2018). However, there was no significant association between the frequency of lesions in the last three decades ( $p=0.74)$. Frequency of lesions in different decades are presented in Table II.

Table II - Frequency of pathological lesions in different decades.

\begin{tabular}{|c|c|c|c|c|c|c|c|}
\hline \multirow[b]{2}{*}{ Lesions } & \multicolumn{2}{|c|}{ 1989-1998 } & \multicolumn{2}{|c|}{ 1999-2008 } & \multicolumn{2}{|c|}{ 2009-2018 } & \multirow[b]{2}{*}{ p-value } \\
\hline & $\begin{array}{c}\text { Number } \\
\text { (No.) }\end{array}$ & $\begin{array}{c}\text { Per- } \\
\text { centage } \\
(\%)\end{array}$ & $\begin{array}{l}\text { Number } \\
\text { (No.) }\end{array}$ & $\begin{array}{c}\text { Per- } \\
\text { centage } \\
(\%)\end{array}$ & $\begin{array}{c}\text { Number } \\
\text { (No.) }\end{array}$ & $\begin{array}{l}\text { Per- } \\
\text { centage } \\
(\%)\end{array}$ & \\
\hline Reactive lesions & 36 & 40 & 79 & 32.9 & 150 & 36.2 & \multirow{7}{*}{0.74} \\
\hline $\begin{array}{l}\text { Squamous Cell } \\
\text { Carcinoma }\end{array}$ & 21 & 23.3 & 51 & 21.2 & 89 & 21.5 & \\
\hline $\begin{array}{l}\text { Other malig- } \\
\text { nancies than } \\
\text { squamous cell } \\
\text { carcinoma }\end{array}$ & 4 & 4.4 & 20 & 8.4 & 38 & 9.2 & \\
\hline $\begin{array}{l}\text { Odontogenic } \\
\text { lesions }\end{array}$ & 6 & 6.7 & 12 & 5 & 23 & 5.6 & \\
\hline $\begin{array}{l}\text { Immunological } \\
\text { and allergic } \\
\text { lesions }\end{array}$ & 7 & 7.8 & 20 & 8.3 & 30 & 7.2 & \\
\hline Other lesions & 16 & 17.8 & 58 & 24.2 & 84 & 20.3 & \\
\hline Total & 90 & 100 & 240 & 100 & 414 & 100 & \\
\hline
\end{tabular}

There was a significant association between the frequency of lesions in different age groups ( $\mathrm{p}<0.001$ ).At higher ages, frequency of squamous cell carcinoma and other malignancies were significantly increased.On the other hand, the frequency of other lesions was significantly decreased with increasing age. Frequency of lesions in different age groups are presented in Table III.
Table III - Frequency of pathological lesions in different age groups.

\begin{tabular}{|c|c|c|c|c|c|c|c|}
\hline \multirow[b]{2}{*}{ Lesions } & \multicolumn{2}{|c|}{ 65-70 year } & \multicolumn{2}{|c|}{ 71-79 year } & \multicolumn{2}{|c|}{ 80-90 year } & \multirow[b]{2}{*}{ p-value } \\
\hline & $\begin{array}{c}\text { Number } \\
\text { (No.) }\end{array}$ & $\begin{array}{l}\text { Per- } \\
\text { centage } \\
(\%)\end{array}$ & $\begin{array}{l}\text { Number } \\
\text { (No.) }\end{array}$ & $\begin{array}{c}\text { Per- } \\
\text { centage } \\
(\%)\end{array}$ & $\begin{array}{l}\text { Number } \\
\text { (No.) }\end{array}$ & $\begin{array}{l}\text { Per- } \\
\text { centage } \\
(\%)\end{array}$ & \\
\hline Reactive lesions & 54 & 16.5 & 71 & 22.1 & 36 & 37.5 & \multirow{7}{*}{$p<0.001$} \\
\hline $\begin{array}{l}\text { Squamous Cell } \\
\text { Carcinoma }\end{array}$ & 120 & 36.7 & 115 & 35.9 & 30 & 31.2 & \\
\hline $\begin{array}{l}\text { Other malig- } \\
\text { nancies than } \\
\text { squamous cell } \\
\text { carcinoma }\end{array}$ & 21 & 6.4 & 28 & 8.7 & 13 & 13.5 & \\
\hline $\begin{array}{l}\text { Odontogenic } \\
\text { lesions }\end{array}$ & 29 & 8.9 & 11 & 3.4 & 1 & 1 & \\
\hline $\begin{array}{l}\text { Immunological } \\
\text { and allergic } \\
\text { lesions }\end{array}$ & 33 & 10.1 & 20 & 6.2 & 4 & 4.2 & \\
\hline Other lesions & 70 & 21.4 & 76 & 23.7 & 12 & 12.6 & \\
\hline Total & 327 & 100 & 321 & 100 & 96 & 100 & \\
\hline
\end{tabular}

\section{DISCUSSION}

Primarily, aging is associated with an increased incidence of oral lesions, and malignant lesions are generally more common in older age [9]. Most oral lesions in elderly are due to use of various drugs and dental prostheses [10]. In fact, aging is a very important factor for many oral diseases and lesions [11,12]. Therefore, in the present study, we evaluated 744 elderly patients in three last decades.

In the present study, the majority of lesions $(55.6 \%)$ were related to the last decade (2009 to 2018). This may be due not to an increase in the prevalence of these lesions in the recent decade, but to a greater awareness of the community and more referrals to diagnostic centers and improved diagnostic methods.Also in the present study, the most reactive lesions were observed in the 65-70 and 71-79 years' age groups; while squamous cell carcinoma (37.6\%) was the most common pathologic lesions in the 80-90 years' age group.

In this study, we observed a significant association between the pathologic lesions and age of the elderly. The frequency of squamous cell carcinoma and other malignancies increased in high age, and the frequency of other pathological lesions were decreased.In a study by Motaleb-Nejad et al. reported that with 
increasing age and longer use of tobacco and prostheses as well as lack of oral hygiene due to disability or reduced motivation, the incidence of lesions increased in the elderly [13],which is similar to the results of the present study.In the several studies by Molania et al., Owlia et al., and Ferreira et al., no significant relationship was observed between the age of elderly and the type of oral lesions $[8,14,15]$.This is in contrast to the results of the present study, which may be due to the large sample size in the present study and presence of the larger number of elderly in a particular age group.

The results of this study showed that the most frequent pathological lesions in the male (36.1\%) and female $(35.1 \%)$ were related to reactive lesions, and there was a no significant difference in the frequency of pathologic diagnosis between male and female elderly. In the several studies by Owlia et al., Mozafari et al., and Corbet et al., reported that there was no significant difference in prevalence of mucosal lesions between male and female elderly $[9,14,16]$.On the other hand, Molania et al., Motaleb-Nejad et al., Lin et al., and Van et al., reported a higher prevalence of lesions in elderly men $[8,13,17,18]$.

In the present study, the most common pre-biopsy lesions in the studied elderly were related to squamous cell carcinoma (24.5\%), Epulis fissuratum (13.4\%), Irritation fibroma (6\%), lichen planus (4.2\%), odontogenic keratocysts (3.1\%). Leukoplakia (1.7\%) and pemphigus $(1.7 \%)$, respectively.In a study by Molania et al. reported that the most common lesions in the elderly were fissured tongue (55.6\%), varicose vein (46.7\%), pigmentation (26.7\%), and candidiasis (25.6\%) [8].

In the study of Motaleb-Nejad et al. the most common oral lesions were related to varicosity (44.7\%), prosthetic stomatitis (18.2\%), varicose veins $(17.8 \%)$ and maxillary prosthetic suction hyperplasia (13.8\%) [13].In another study by Mozafari et al. reported the most common oral lesions related to fissured tongue, atrophic glossitis, and sublingual varicosity [9].
In the present study, the most common pathologic lesions were related to the Reactive lesions, squamous cell carcinoma, nonsquamous cell carcinoma, and odontogenic lesions, which is similar to the results reported by Silva et al., Lei et al., Dhanuthai et al., and Souza et al. [19,20,21,22], in contrast to the results of Mohan et al., who reported malignant neoplastic lesions as the most common lesion in elderly [23].The differences in the studies may be due to involvement of environmental-social and lifestyle factors in different geographical areas.

\section{CONCLUSION}

In general, our study showed a high prevalence of oral pathologic lesions in elderly in Isfahan, Iran.According to the present study, and significant frequency of oral lesions and malignant lesions in elderly,periodic examinations are necessary to better management and prevention of oral lesions in elderly.Therefore, it is recommended that researchers focus on interventional studies to provide more effective strategies for prevention and appropriate treatment of oral lesions in elderly. Also, similar studies should be carried out in other dental centers in the world.

\section{Conflict of interest}

The authors have no proprietary, financial, or other personal interest of any nature or kind in any product, service, and/or company that is presented in this article.

\section{Regulatory Statement}

This study was conducted in accordance with all the provisions of the local human subjects oversight committee guidelines and policies of: Isfahan University of Medical Sciences. The approval code for this study is: IR.MUI.RESEARCH.REC.1398.129.

\section{REFERENCES}

1. Modanloo MM, Ziaea T, Behnampour N. Dental health status in elderly (Gorgan-Iran). J Gorgan Univ Med Sci. 2010;12(3):68-73. 
2. Raoufi S. Investigate causes of the fall of the elderly Aligoodarz in 2006. J Aflak Lorestan Univ Med Sci. 2006;2(48):4-5.

3. GhaderiS, Sahaf R, Mohammadi ShahbalaghiF,Ansari G, Gharanjic A, Ashrafi $\mathrm{K}$, et al. Prevalence of depression in elderly kurdish community residing in boukan, Iran. Iran J Age. 2012;7(1):57-66.

4. Shiralizadeh J,BarmakiH, Haiaty S, Faridvand Y,Mostafazadeh M, Mokarizadeh N, etal. The effects of high and low doses of folic acid on oxidation of protein levels during pregnancy: a randomized double-blind clinical trial. Horm Mol Biol Clin Investig. 2017;33(3):/j/hmbci.2018.33.issue-3/ hmbci-2017-0039/hmbci-2017-0039.xml. doi:10.1515/hmbci-2017-0039

5. Hajizadeh YS, Emami E, Nottagh M, Amini Z, Maroufi NF, Azimian SH, et al. Effects of interleukin-1receptor antagonist (IL-1Ra) gene 86 bp VNTR polymorphism on recurrent pregnancy loss: a case-control study. Horm Mol Biol Clin Investig.2017;30(3):/j/hmbci.2017.30.issue-3/hmbci-2017-0010/ hmbci-2017-0010.xml.. doi:10.1515/hmbci-2017-0010

6. Nasirpour H, Key YA, Kazemipur N, Shadman B, Hajazimian S, Taefehshokr $\mathrm{S}$. The effects of cholesterol lowering drugs on vitamin D status in familial hypercholesterolemia patients. Arch Med Lab Sci. 2017;3(4):29-33

7. Kosari M, hoseiniZ, Golrizi F. The investigation of oral and dental status and its related factors in the elderly in Torbat Heydariyeh in 2015. J Health Chimes. 2016;4(2):39-44.

8. Molania T,Mousavi SJ, Ahangari M, Salehi M. Prevalence of oral mucosal lesions in nursing home from dental school foundation up to 2010. Mash Dent Sch. 2013;37(2):127-36.

9. MozafariPM,DalirsaniZ,DelavarianZ, Amirchaghmaghi M, Shakeri MT,Esfandyari A, et al. Prevalence of oral mucosal lesions in institutionalized elderly people in Mashhad, Northeast Iran. Gerodontology. 2012;29(2):e930-e934. doi:10.1111/j.1741-2358.2011.00588.x

10. Shulman JD, Beach MM, Rivera-Hidalgo F. The prevalence of oral mucosal lesions in U.S. adults: data from the Third National Health and Nutrition Examination Survey, 1988-1994. J Am Dent Assoc. 2004;135(9):1279-86. doi:10.14219/jada.archive.2004.0403

11. SaberiZ, Pakravan F,Mohsenzadeh L. Prevalence of oral mucosal status in resident and non-resident nursing home in Isfahan city, Iran: a comparative cross-sectional study. Braz Dent Sci. 2019;22(4):475-82. doi:10.14295/bds.2019 v22i4.1750
12. Shay K Restorative considerations in the dental treatment of the older patients, geriatric Dentistry. Gen Dent. 2000;48(5):550-4.

13. Motaleb Nejad M, Shirvani M. Oral mucosal lesions in elderly population, Tehran Kahrizak Geriatric Institute,2000. J Babol Univ Med Sci. 2002;4(3):28-33.

14. OwliaF,Ahadian H, Rustaei zadehZ, Bahadori L The Prevalence of Oral Lesion among Elderly in Yazd Province Nursing Homes in 2014. J Health. 2017;8(3):3217.

15. Ferreira RC, MagalhãesCS, Moreira AN. Oral mucosal alterations among the institutionalized elderly in Brazil. Braz Oral Res. 2010;24(3):296-302. doi:10.1590/ s1806-83242010000300007

16. CorbetEF,Holmgren CJ, Phillipsen HP. Oral mucosal lesions in 65-74-year-old Hong Kong Chinese. Community Dent Oral Epidemiol. 1994;22(5 Pt2):392-5. doi:10.1111/.1600-0528.1994.tb01599.x

17. Lin HC, Corbet EF, Lo EC. Oral mucosal lesions in adult Chinese.J Dent Res. 2001;80(5):1486-90. doi:10.1177/00220345010800052001

18. van Wyk CW, Farman AG, Staz J. Oral health status of institutionalized elderly Cape Coloreds from the Cape Peninsula of South Africa. Community Dent Oral Epidemiol. 1977;5(4):179-84. doi:10.1111/j.1600-0528.1977.tb01636.

19. Silva LP, Leite RB, Sobral AP,Arruda JA, Oliveira LV, Noronha MS, et al. Oral and maxillofacial lesions diagnosed in older people of a brazilian population: a multicentric study. J Am Geriatr Soc. 2017;65(7):1586-90. doi:10.1111//jgs.14815

20. Lei F,Chen JY,Wang WC, etal. Retrospective study of oral and maxillofacial lesions in older Taiwanese patients. Gerodontology.2015;32(4):281-7. doi:10.1111/ ger.12118

21. Dhanuthai K, Rojanawatsirivej S, Somkotra T, Shin Hl,Hong SP,Darling M, etal. Geriatric oral lesions: a multicentric study. Geriatr Gerontol Int. 2016;16(2):23743. doi:10.1111/ggi.12458

22. SouzaS, Alves T, Santos J, Oliveira M. Oral lesions in elderly patients in referral centers for oral lesions of Bahia. Int Arch Otorhinolaryngol. 2015;19(4):279-85. doi:10:1055/s-0035-1554727

23. Mohan BC, Angadi PV, Hallikerimath S, Kale AD. Diagnoses of 964 oral biopsies from people aged over 50 years in Karnataka State, India. Gerodontology. 2016;33(2):217-24. doi:10.1111/ger.12143

\section{Neda Kargahi}

(Corresponding address)

Department of Oral and Maxillofacial Pathology, Dental Research Center, Dental Research Institute,School of Dentistry, Isfahan University of Medical Sciences, Isfahan, Iran.

Email: kargahi@dnt.mui.ac.ir

Date submitted: 2019 Jan 25

Accept submission: 2020 Jun 30 